\title{
СОЦІОЛОГІЧНЕ ДОСЛІДЖЕННЯ ОБІЗНАНОСТІ МОЛОДІ КОНОТОПСЬКОГО РАЙОНУ 3 ПРОБЛЕМАМИ ПОШИРЕННЯ ПІДЛІТКОВОГО АЛКОГОЛІЗМУ
}

\author{
I. В. Лисюк
}

\section{Конотопське медичне училище}

У статті проаналізовано соціокультурний механізм залучення підлітків та молоді до вживання алкоголю, визначені фактори, що сприяють розвитку алкоголізму серед підлітків, з'ясовано ставлення молоді до проблеми алкоголізму.

\section{SOCIOLOGICAL RESEARCH OF KNOWLEDGE ATTITUDE OF TEENAGERS WITH DRINKING EXPANSION AMONG YOUNG ADULTS IN KONOTOP REGION}

\section{V. Lysuk}

\section{Konotop Medical School}

The article analyzes the sociocultural mechanism of teenagers' and young adult's attraction to alcohol, defines factors contributing to the development of alcoholism among teenagers, and identifies the young adult's concern to the problem of alcoholism.

Вступ. У ході дослідження розроблено анкетування з метою виявлення рівня обізнаності підлітків з питань алкоголізму та встановлення причин вживання алкогольних напоїв підлітками та запропоновано заходи боротьби з підлітковим алкоголізмом. Питання в анкеті розроблено таким чином, щоб визначити ставлення підлітків до алкоголю та до споживачів цих спиртних напоїв, схильність підлітків до вживання алкоголю; можливі причини вживання алкоголю підлітками, інформованість підлітків про шкоду алкоголю; залучення підлітків до процесу алкоголізації; ставлення підлітків до вживання алкоголю, заходи профілактики алкоголізму серед молоді.

Основна частина. Впродовж 2015-2016 рр. було опитано 130 респондентів (підлітків віком від 15 до 20 років) Конотопського медичного училища. Серед респондентів були як представники чоловічої статі (43\%), так і жіночої (57 \%).

Отже, за даними діаграми (рис. 1) більшість підлітків (83 \%) мала спробу вживання алкоголю.

Аналіз даних діаграм свідчить про те, що пік першої спроби алкоголю припадає на 14-15 років (рис. 2).

Тому, за даними соціологічного дослідження, більшість опитаних представників молодого покоління Конотопського району має досвід знайомства з

(C) І. В. Лисюк, 2017 алкогольними напоями, при чому активне вживання алкоголю збільшується в міру дорослішання підлітків і притаманне як хлопцям, так і дівчатам. Реальним виходом із цієї ситуації на сьогодні є активне залучення до профілактичної роботи педагогів, психологів, представників інших установ сфери освіти, а також батьків $[1,2]$.

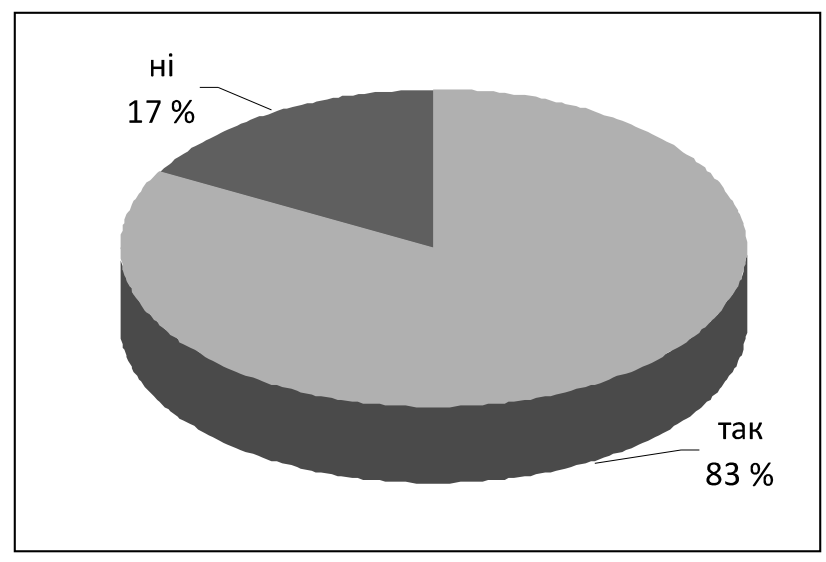

Puc. 1. Питома вага підлітків, які мають досвід вживання спиртних напоїв.

До 11 років перше знайомство з алкоголем відбувається або випадково, або його дають «для апетиту», «лікують» вином, або ж дитина сама з цікавості пробує спиртне. У старшому віці це частіше трапляється 3 


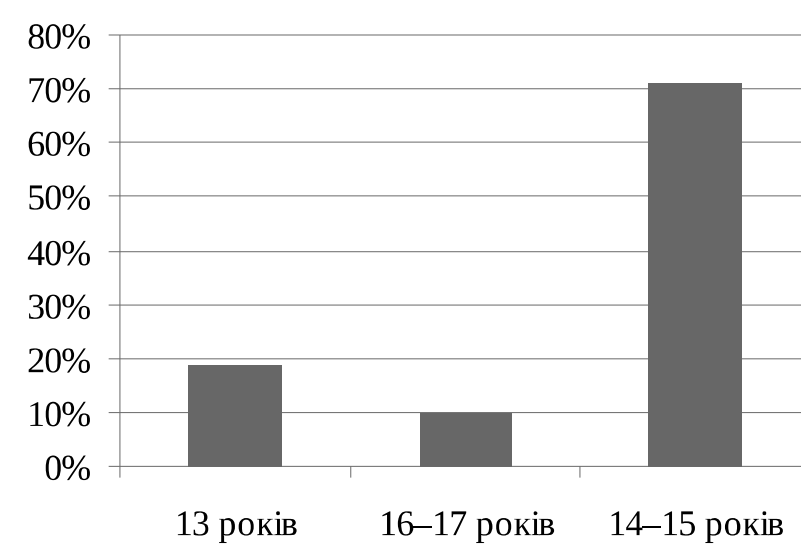

Puc. 2. Вік першого вживання алкогольних напоїв.

традиційного приводу: «свято», «сімейні урочистості», «гості». Зазвичай, це буває, так би мовити, «безневинна» чарочка на честь дня народження або іншого свята. I хоча це відбувається за згодою батьків, у колі родини, все ж і таке привчання дітей до вина небезпечне. Адже варто раз доторкнутися до спиртного, як уже знімається психологічний бар'єр - і підліток вважає, що він уже має право випити з товаришами або навіть сам, якщо з'явиться така можливість.

За даними наших досліджень, перше враження від випитого спиртного було неприємним (49\%), ініціаторами вживання алкоголю були друзі (55 \%), власна ініціатива (38 \%), батьки (7 \%), а причинами першої спроби вживання алкоголю було свято (66 \%), через цікавість - лише $22 \%$. За даними опитування, 54 \% респондентів вважає нормальним вживати спиртні напої нечасто («на свята») і в обмеженій кількості.

Одним із визначальних чинників у мотивації вживання спиртного підлітком $€$ вплив однолітків, друзів, старших підлітків. $94 \%$ респондентів мають друзів, які вживають алкоголь.

Досить популярними у молодіжному середовищі сьогодні є слабоалкогольні напої, які з кожним роком стають ще більше популярними та доступними $[1,2]$. Усі ці дані підкреслюють необхідність профілактичної роботи з молоддю саме з акцентом на наслідки вживання та надмірного вживання алкоголю для самого підлітка та його оточення (рис. 3).

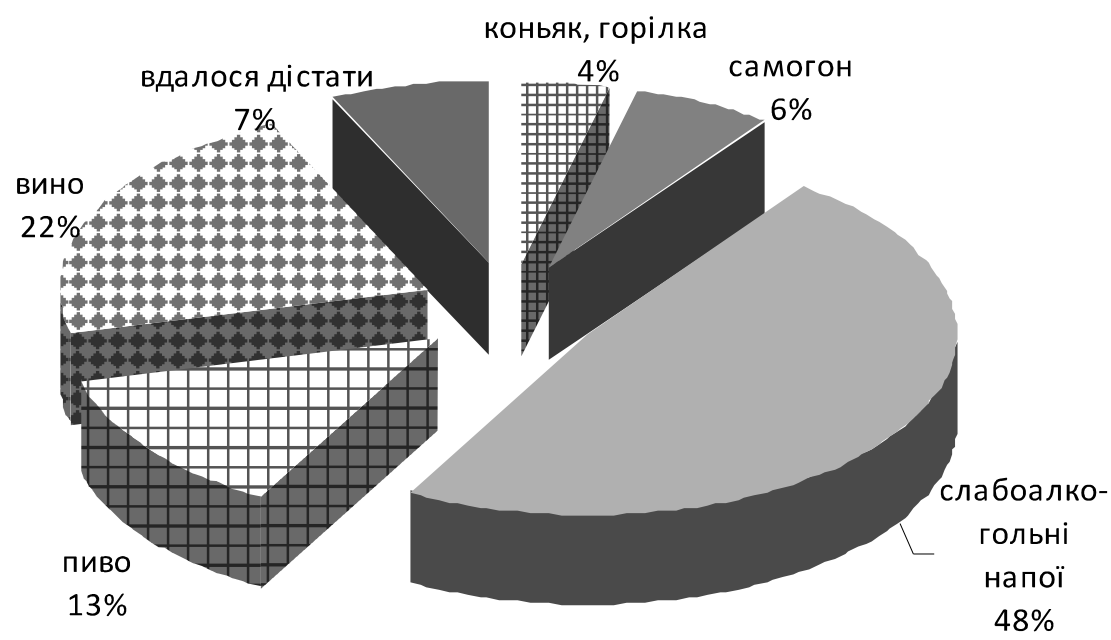

Puc. 3. Види алкогольних напоїв, яким надає перевагу молодь.

Для 95 \% респондентів дуже ймовірним наслідком вживання алкоголю $є$ шкода для здоров'я. Можна припустити, що ці учні досить поінформовані щодо наслідків вживання алкоголю.

Серед причин пияцтва респонденти на перше місце винесли вплив друзів - 52 \%; на друге - приклад дорослих (17\%); на третє - відсутність інтересів та домашні конфлікти; на четвертому місці - відсутність місць відпочинку серед молоді (рис. 4).

За результатами анкетування, ми з'ясували доступність алкогольних напоїв для підлітків. Отже, 46 \% респондентів вважають, що дістати алкоголь легко;
27 \% - не знають; і лише 25 \% вважають, що алкоголь дістати складно; 2 \% - неможливо (рис. 5).

Алкогольні напої заборонено продавати неповнолітнім. Але підлітки знаходять можливості купити алкоголь, зазвичай просять старших товаришів, які їм не відмовляють. Саме тому, в першу чергу, потрібно дотримуватися законодавства. А соціальні служби і правоохоронні органи мають належно контролювати його виконання. Серед основних причин поширення пияцтва серед молоді фахівці називають доступність алкоголю та вплив реклами. 


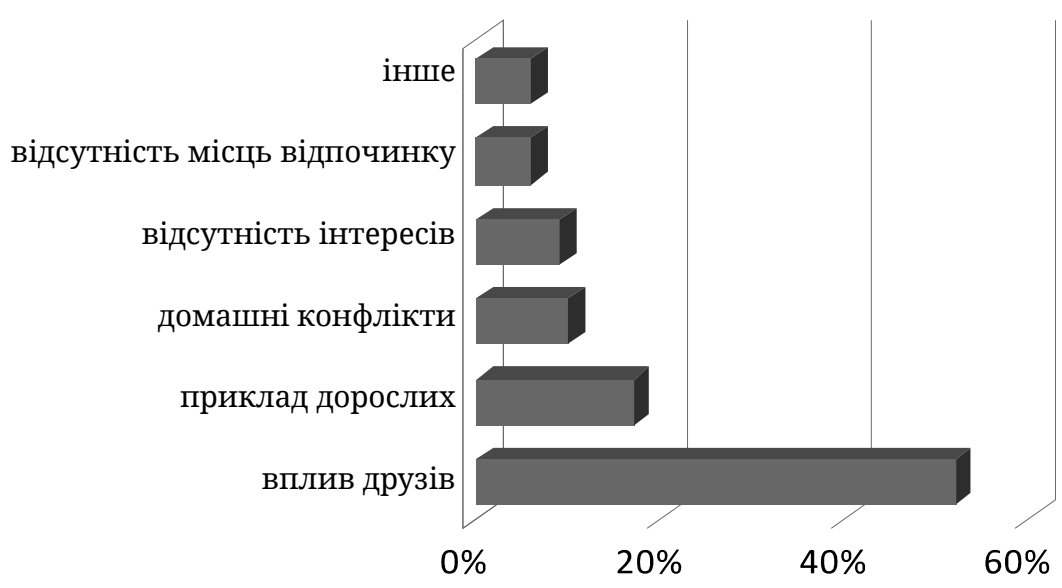

Puc. 4. Причини алкоголізму серед молоді.

Алкоголь - це наркотик із тяжкими наслідками. Як і всі наркотичні речовини, він викликає залежність. Вживання слабоалкогольних напоїв та пива може викликати залежність від алкоголю так само, як вино, горілка, коньяк. Хвороба формується поступово, непомітно для оточуючих і самого неповнолітнього. Через особливості підліткового організму алкогольна залежність розвивається у підлітків значно швидше, ніж у дорослих. За результатами анкетування, більшість респондентів вважає, що відмовитися від спиртного буде легко (88 \%); 12 \% важко відповісти - це говорить про алкогольну залежність підлітка.

Серед підлітків було здійснено опитування з приводу наслідків вживання спиртних напоїв. Результати виявилися такі: лише 17 \% мали проблеми через алкоголь (втрата грошей та інших коштовних речей, проблеми у взаєминах із батьками, друзями; зни- ження працездатності в процесі навчання та в інших видах діяльності).

Загальновідомо, що будь-яку хворобу легше попередити, ніж лікувати. Алкоголізм - не виняток, оскільки $\epsilon$ тяжким фізичним і психічним захворюванням. Відтак, велике значення мають методи боротьби з пияцтвом серед молоді [3]. Студентам було поставлено таке запитання: Які заходи ви вважаєте найбільш ефективними в боротьбі з пияцтвом серед молоді, а саме в навчальному закладі? За результатами опитування отримали такі дані (рис. 6, 7): 28 \% вважають найбільш діючим - скорочення доступності спиртних напоїв; 24 \% - посилення заходів кримінального покарання за злочин та правопорушення, скоєні у п'яному вигляді; $17 \%$ - введення «сухого закону»; 14 \% - розширення структури безалкогольних барів та кафе, дискотек; 11 \% - залучення засобів масової інформації зпитань пропаганди тверезого способужиття.

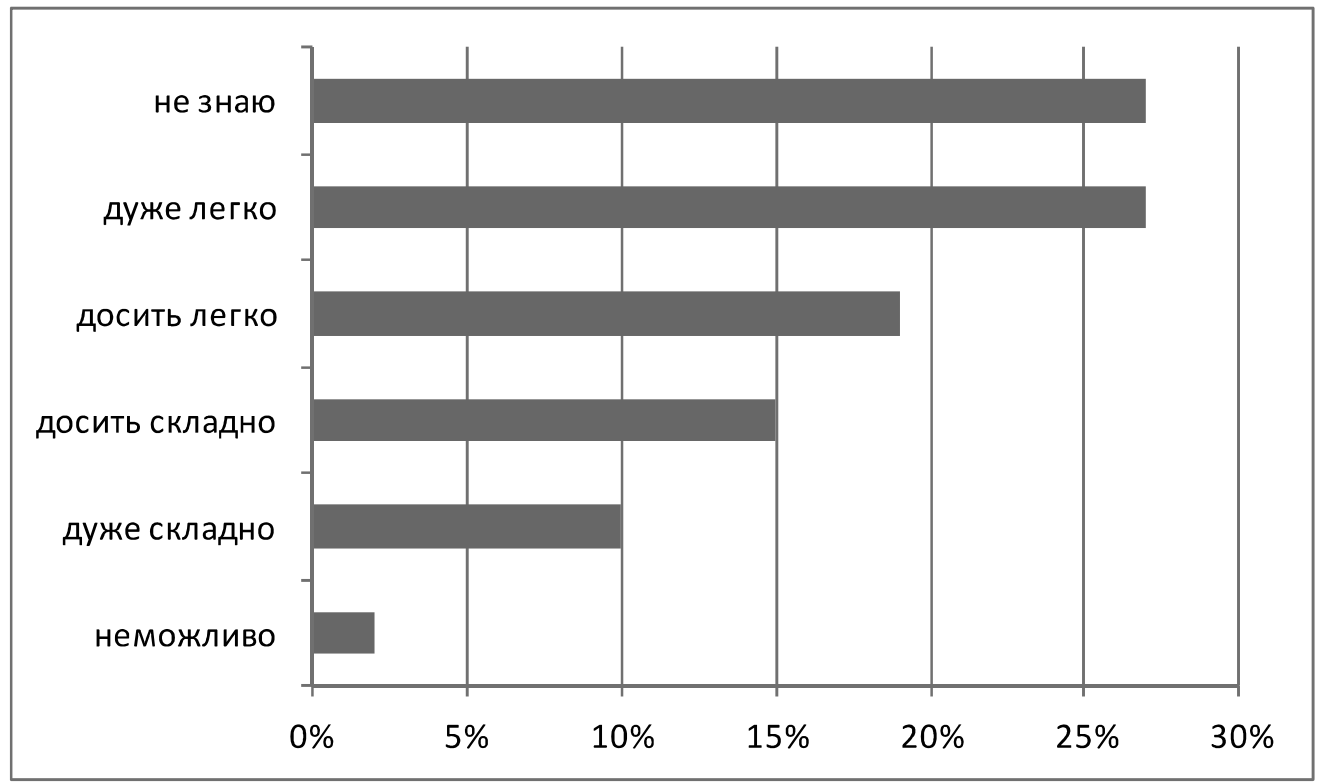

Puc. 5. Доступність алкоголю підліткам. 


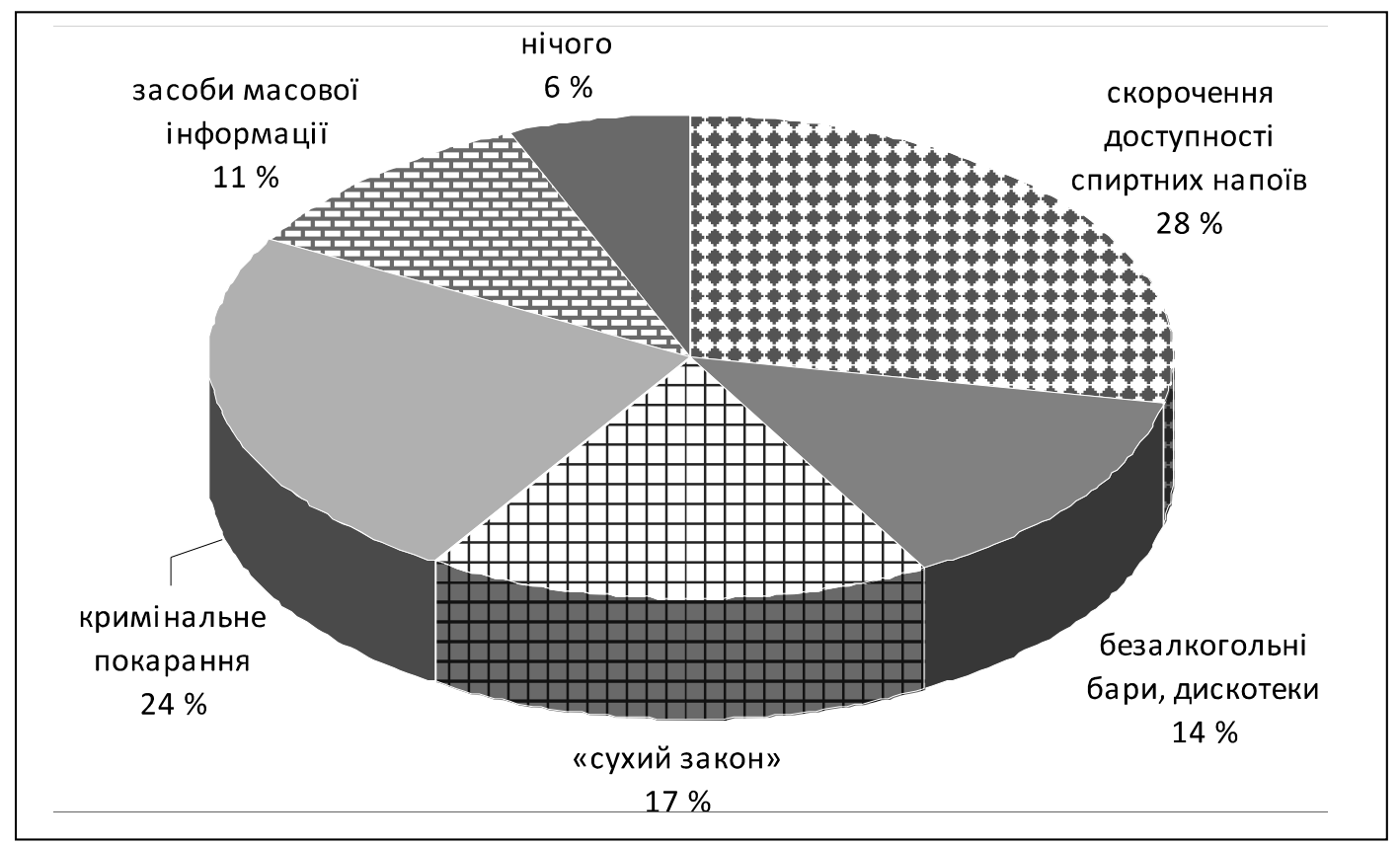

Puc. 6. Методи боротьби з пияцтвом серед молоді.

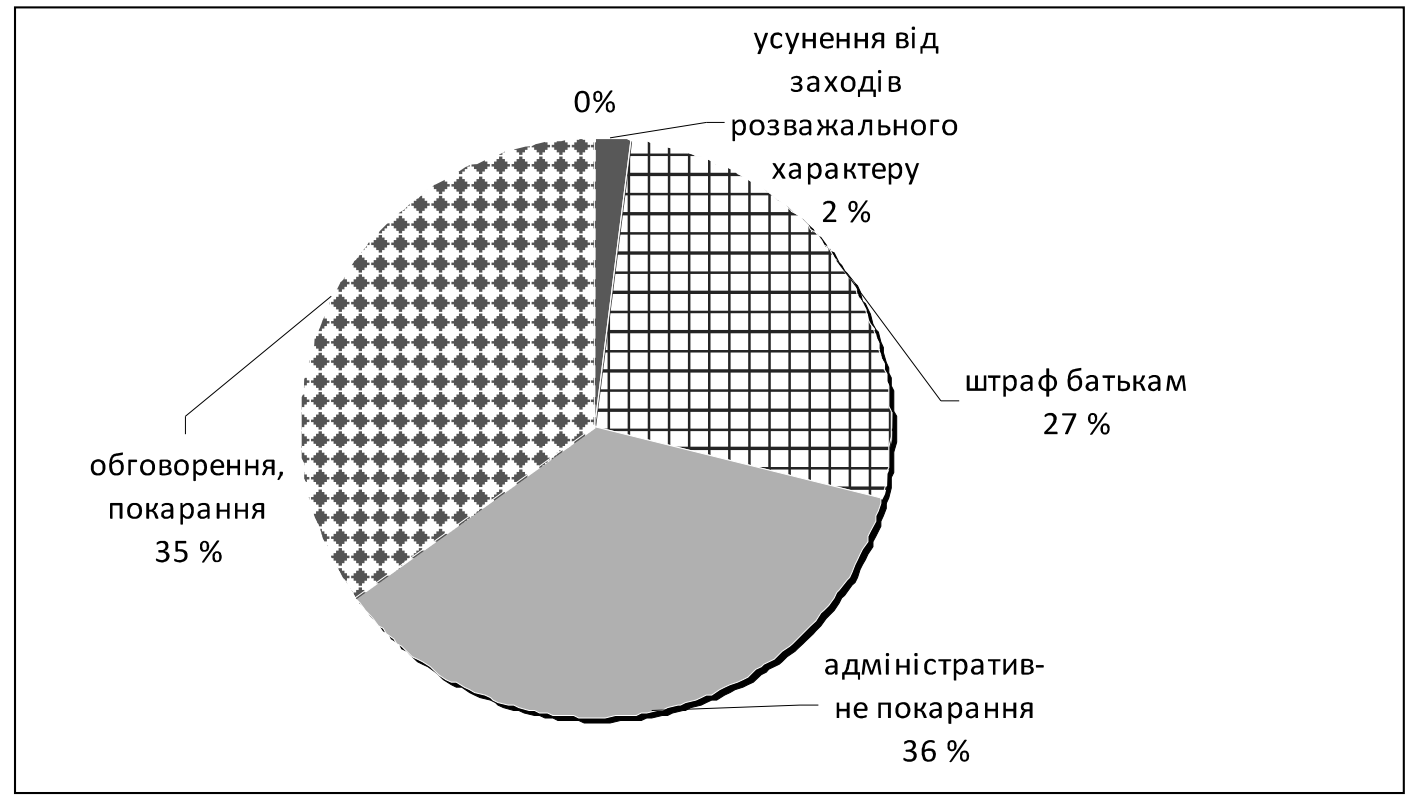

Puc. 7. Заходи боротьби з пияцтвом у навчальному закладі.

Висновки. За результатами анкетувань можна зробити висновки про негативне ставлення сучасної молоді до алкоголізму. Відтак, освітні заклади разом із громадськістю повинні врахувати соціальні, пси-

\section{СПИСОК ЛІТЕРАТУРИ}

1. Балакірєва О. М. Рівень поширення і тенденції вживання тютюну, алкогольних напоїв, наркотичних речовин серед учнівської молоді України: 2011 / [Т. В. Бондар, Ю. П. Галіч та ін.]. - К. : Обнова, 2011. - 176 с.

2. Перепелиця М. П. Державна молодіжна політика в Україні (регіональний аспект) / М. П. Перепелиця // хологічні, освітньо-культурні потреби підлітків і захистити молоде покоління від небезпеки алкогольної залежності.

Український інститут соціальних досліджень, Український центр політичного менеджменту. - К., 2007. - 52 с.

3. Спрангер Б. Е. Аналіз стану навчальних програм «Формування життєвих навичок» в світі / Б. Е. Спрангер // Питання. - 2004. - № 1. - С. 82-85. 